NBER WORKING PAPER SERIES

\title{
THE IMPACT OF INTERNET SUBSIDIES IN PUBLIC SCHOOLS
}

\author{
Austan Goolsbee \\ Jonathan Guryan \\ Working Paper 9090 \\ http://www.nber.org/papers/w9090 \\ NATIONAL BUREAU OF ECONOMIC RESEARCH \\ 1050 Massachusetts Avenue \\ Cambridge, MA 02138 \\ August 2002
}

We wish to thank Joshua Angrist, David Autor, Thomas Hubbard, Steven Levitt, Kevin Murphy and workshop participants at the University of Chicago, the University of Virginia and the ASSA meetings for helpful comments, and Catriona Ayer, Monique Nelson, Duncan Chaplin and the Urban Institute for providing data, and Tina Lam and Clarissa Yeap for research assistance. Goolsbee thanks the National Science Foundation (SES 9984567), the Alfred Sloan Foundation and the American Bar Foundation for financial support. The views expressed herein are those of the authors and not necessarily those of the National Bureau of Economic Research.

(C) 2002 by Austan Goolsbee and Jonathan Guryan. All rights reserved. Short sections of text, not to exceed two paragraphs, may be quoted without explicit permission provided that full credit, including $(\mathrm{C}$ notice, is given to the source. 
The Impact of Internet Subsidies in Public Schools

Austan Goolsbee and Jonathan Guryan

NBER Working Paper No. 9090

August 2002

JEL No. I2, H2

\begin{abstract}
In an effort to alleviate the perceived growth of a digital divide, the U.S. government enacted a major subsidy for Internet and communications investment in schools starting in 1998. The program subsidized spending by 20-90 percent, depending on school characteristics. Using new data on school technology usage in every school in California from 1996 to 2000 as well as application data from the E-Rate program, this paper shows that the subsidy did succeed in significantly increasing Internet investment. The implied first-dollar price elasticity of demand for Internet investment is between -0.9 and -2.2 and the greatest sensitivity shows up among urban schools and schools with large black and Hispanic student populations. Rural and predominantly white and Asian schools show much less sensitivity. Overall, by the final year of the sample, there were about 66 percent more Internet classrooms than there would have been without the subsidy. Using a variety of test score results, however, it is clear that the success of the E-Rate program, at least so far, has been restricted to the increase in access. The increase in Internet connections has had no measurable impact on any measure of student achievement.
\end{abstract}

Austan Goolsbee

Graduate School of Business

University of Chicago

1101 E. 58th Street

Chicago, IL 60637,

American Bar Foundation and NBER

goolsbee@gsb.uchicago.edu
Jonathan Guryan

Graduate School of Business

University of Chicago

1101 E. 58th Street

Chicago, IL 60637

and NBER

jonathan.guryan@gsb.uchicago.edu 


\section{Introduction}

As the Internet has grown over the last five years, inequality of access and understanding of technology across income and racial lines has led to concern among policymakers about the so-called digital divide. It has generated many proposals to help close the divide, by both governments and private entities like the Gates Foundation.

Policymakers and analysts have argued that public schools are the natural place to teach underserved populations about computers. As part of the Telecommunications Act of 1996, the government began actively subsidizing Internet and telecommunications access in U.S. classrooms and libraries through a tax on long-distance services as a new, information-age component of the Universal Service Fund. This new initiative, known as the E-Rate program, began in 1998 and provides up to $\$ 2.25$ billion per year of subsidies to school and library investment in Internet and communications technology. To understand the magnitude of this subsidy, note that Lake (2000) estimates total public school spending on computers in 1999 (including hardware, software, training, networking, etc.) was only $\$ 3.3$ billion. The E-rate subsidy is, by far, the most ambitious federal technology program in schools.

Understanding the extent to which the $\$ 2.25$ billion subsidy fulfilled its primary goal of increasing Internet usage in schools, particularly disadvantaged ones, versus merely subsidizing spending that was already taking place, is thus of first order importance. There is also considerable interest in — and debate about—whether spending on computers and information technology has any impact on student performance (see Kirkpatrick and Cuban, 1998; Angrist

\footnotetext{
${ }^{1}$ This tax itself is not without controversy as Hausman (1998) suggests it generates more than a dollar of efficiency cost for every dollar it raises.

${ }^{2}$ It is also large by the standards of other universal service subsidies. Crandall and Waverman (2000), for example, calculate that the annual cost of universal service subsidies for telephone service was less than \$2.2 billion (in 1998), for electricity less than $\$ 1.2$ billion (in 1990), and for natural gas about $\$ 1.5$ billion (in 1995).
} 
and Lavy, 1999; Cuban, 2001) and the creators of the E-rate have argued that it can do more than just increase access, that it can improve basic student performance.

In this paper we provide an economic analysis of the impact of the E-Rate program on public schools' technology adoption over the 1996-2000 period. To do so, we use new data on the technology owned in each year by every school in California. We merge these with administrative data on every E-Rate funding application these same schools filed, including the amount of funding, the subsidy rate, and purpose of the funding. We also use demographic data for each school and district from the National Center for Education Statistics Common Core of Data (CCD) and the 1990 U.S. Census.

We seek to determine whether schools with higher subsidy rates appeared to make greater investments in technology than they would have without the program and, if so, whether the increase in Internet access had any impact on observed student outcomes in the period. To do so, we must confront three difficulties in analyzing the program.

First, there is a clear upward trend in Internet access among public schools well before the program began. The data in U.S.D.O.E. (2000) on the share of public school classrooms with access to the Internet, for example, shows the share increasing by a factor of five from 1994 to 1996 (from 3\% in 1994 to 15\% in 1996) followed by continued growth through 1999 (51\% in 1998 and 63\% in 1999). While it is true that the time series shows a major increase in access in the first year of the E-rate program, it is important to distinguish the program's effect from underlying trends. We do this by exploiting cross-sectional variation in the subsidy rate across schools in the same time periods and by looking at growth rates rather than levels.

The second problem we deal with is the fact that the cross-sectional variation in the subsidy rate (the subsidy rates range from 20 to 90 percent) depends on factors, such as the share 
of pupils qualifying for subsidized school lunches, which are likely to be correlated with unobserved tastes for technology in the school. To address these issues we include flexible controls for the previous technology histories of these schools as well as the very school demographic characteristics that drive the variation in subsidy rates.

The third problem, which leads to an independently interesting observation, is that districts are allowed to selectively include schools on subsidy applications. The progressive nature of the subsidy creates a stronger incentive for high-poverty districts to apply for funds. The fact that the subsidy rate is determined by the combined school lunch percentage of participating schools creates an incentive for wealthy schools to convince high-poverty schools in the district to join their applications. We show evidence that districts and schools do respond on both margins in predictable ways. While this observation is interesting as a window into the workings of public schools, the resulting selection might lead to bias in our estimates. We are careful to deal with this selection when estimating the impact of the subsidy on adoption rates.

The paper proceeds in eight parts. In section II, we describe the rules and history of the E-Rate program. In section III, we describe the data and present summary statistics. In section IV we present the identification framework. In section $\mathrm{V}$ we present the basic results. In section VI, we examine which schools were more or less sensitive to the subsidy. And, in section VII present results on student outcomes. In section VIII we conclude.

\section{The E-Rate Program}

On May 7, 1997, the Federal Communications Commission (FCC) adopted a Universal Service Order implementing the Telecommunications Act of 1996. The Order was designed to give all eligible schools and libraries affordable access to modern telecommunications and 
information services. The program began on January 1, 1998 and provided up to $\$ 2.25$ billion annually (FCC, 1997a). It is known as the E-Rate program.

The E-Rate program was not designed to have the government provide technology to schools but rather to subsidize schools' purchases of such technology and to do so at a progressively sliding rate that depends on poverty rates and urban/rural status. The subsidy rate ranges from 20 to 90 percent depending on the share of students that qualify for the national school lunch program as shown in table 1 .

The subsidy can be used for spending on "all commercially available telecommunications services, Internet access, and internal connections." This includes services like basic telephone service, a T-1 line, telecommunications wiring, routers and switches, Local Area Networks, PBX or other services whose primary purpose is delivering services into classrooms or other places of instruction. Support for administrative functions of a library or school is permitted if it is "part of the network of shared services for learning." (Department of Education, 1997a). Schools cannot get subsidies for things like software, content or computers since they are not directly related to connections. Detailed information on what is eligible can be found in FCC (2001).

Schools may apply for the program individually or as a school district. ${ }^{\boxplus}$ The subsidy rate for individual schools is determined by the criteria in table 1. The subsidy rate for the district is based on the average share of school lunch eligible students across all participating schools (weighted by enrollment) but the rules require that the higher-level entities "must strive to ensure that each school receives full benefit of discount to which entitled" (U.S.D.O.E., 1997b).

\footnotetext{
${ }^{3}$ Note that the E-Rate subsidy is large compared to the computer budget of the schools but tiny compared with overall school spending. This makes it extremely unlikely that schools would attempt to modify their school lunch percentages (which are the basis of most other federal programs, as well) to get above the kink points of the E-Rate subsidy schedule. Direct investigation also shows no evidence that schools altered eligibility percentages in response to the E-rate subsidy rules.

${ }^{4}$ Technically, schools may also apply across districts as consortia but this is extremely rare in practice and we exclude the few consortia from our analysis.
} 


\section{Data}

The data are drawn from three sources. First, data from the U.S. and California Departments of Education give information on every public school in California. Well known data include enrollment counts by race, characteristics of teachers, and the fraction of students eligible for the federal free and reduced price lunch programs. We also use new data, starting in the 1996-1997, which include detailed school level information on the number of computers used for instructional purposes and of the number of classrooms with Internet access in each school. Additional demographic characteristics from the school district-level tabulation of the 1990 census, such as the median household income and the median home value are added.

The California data are merged with the second data set: administrative data from the Universal Service Administrative Company (USAC) on every E-Rate subsidy application over the life of the program. Each application lists the total funds requested, the total funds granted, the subsidy rate that applies to the request and a classification of the funds as Internet access, telecommunications services, or internal connections. The breakdown of E-Rate funding by intended use is shown in table 2. Eighty percent of E-Rate funds go to internal connections, 17 percent go to telecommunications services, and the remaining 3 percent are used for Internet access.

For our analysis, we drop E-Rate applications by libraries, private schools and multidistrict consortia, which, combined, account for only about 10 percent of E-Rate spending in California. To get a subsidy rate for each school, we aggregate the application data to the school district level and use the average subsidy faced by applicant schools in the district. ${ }^{\square}$ The district-

\footnotetext{
${ }^{5}$ The standard errors are corrected to account for within-district correlation resulting from the fact that there is not school level variation in the subsidy rate every year.
} 
level data include funds requested and granted by type of request, and various measures of the subsidy rate, such as the mean, median, and mode. ${ }^{1}$ Since schools within the district can strategically apply in light of the progressive subsidy rate, we compute the subsidy rate as if all the district's schools applied. As shown in section VI, the results do not substantively change if the predicted discount rate is used in its place.

Table 2 also summarizes the Internet and computer access in California's public schools over time. By the 1997-1998 school year, the year before the first E-Rate funding was awarded, 55 percent of California's public schools had at least one classroom with Internet access, an increase of 9 percentage points from a year earlier. Using the number of teachers as a measure of the number of classrooms, we estimate that 26 percent of classrooms in California had Internet access. ${ }^{\text {G }}$ In contrast, 93 percent of California schools used at least one computer for instructional purposes in 1997-1998, while the average school had 2.2 computers per teacher.

As the E-Rate funds grew, Internet access was becoming more widespread. By 20002001, 85 percent of California schools had at least one classroom with Internet access, while two-thirds of all classrooms in California had Internet access. The fraction of California schools that used at least one computer for instructional purposes grew to 98 percent by 2000-2001, while the number of computers per teacher grew to 3.1 .

Over the same time period, the federal government transferred almost $\$ 937$ million to the public schools of California as a part of the E-Rate program. As has been shown in more detail in Puma et. al. (2000), the bottom panel of table 2 shows the total E-Rate funding commitment both nationally and in California. As is shown by the aggregate numbers, national E-Rate

\footnotetext{
${ }^{6}$ We have done the analysis using the district level median, mode, maximum and minimum of the subsidy rate. The results are not qualitatively different. We report only results using the mean due to space concerns.

${ }^{7}$ The number of teachers is almost surely an overestimate of the number of classrooms. Thus, our estimate of the fraction of classrooms with Internet access is a lower bound.
} 
funding grew from $\$ 1.7$ billion in 1998-1999 to $\$ 2.1$ billion in 2000-2001. About 15 percent of that funding went to applicants in California, where there was a sharp increase in requests in 2000-2001. This increase is entirely explained by the $\$ 230$ million in E-Rate funding that the Los Angeles Unified School District received that year. ${ }^{\text {a }}$ The next row of table 2 shows similar estimates of the trend in E-Rate funding using the data in our sample

The strong time-series correlation between the spread of Internet access and the advent of E-Rate funding does not, of course, establish a causal link. The E-Rate legislation was passed in the midst of a strong upward trend in the fraction of schools with Internet access. Thus, even in the absence of the federal subsidy, many school districts may have chosen to make Internet investments. In other words, while the intent of the E-Rate subsidy was to create marginal incentives for school districts to invest in Internet access and to help disadvantaged schools especially, much of the total funds disseminated under the E-Rate program may have gone to inframarginal districts. It is thus instructive to document which districts received E-Rate funding.

Returning to table 1, we can consider who, on average, received disproportionate funds from the E-Rate program. On one hand, the E-Rate subsidy is more generous for poor districts, so funding might be greater for the poorer schools. On the other hand, these poor districts tend to have less technology. Rich districts may have more investment spending on computers and the Internet and therefore get the lion's share of the subsidy money, despite having a lower subsidy rate. The data suggest that, in fact, the first consideration overwhelmed the second. The table shows that a greater share of the funds went to the poorer schools than would be expected by enrollment alone. Most of the E-Rate funds went to schools with subsidy rates of 80 and 90 percent—schools with more than 50 percent of their students eligible for free or reduced price

\footnotetext{
${ }^{8}$ We repeated the analysis in the paper excluding Los Angeles and the results were not affected.
} 
lunch from the federal government. The table also shows that the schools that received more generous subsidies had fewer Internet classrooms prior to the E-Rate program. Thus, E-Rate funding went disproportionately to schools with higher poverty rates and fewer Internet classrooms.

Figures 1 and 2 illustrate the data underlying the regressions in the next section. Figure 1 shows the average fraction of classrooms per district with Internet access. The yearly averages are shown separately for each of five groups of districts. Group 1 are the richest districts-those with less than 20 percent of their students eligible for the federal free or reduced lunch programs in 1997-1998. These districts received the least generous E-Rate subsidy. Group 2 are districts with between 20 and 40 percent of their students eligible for the federal free or reduced lunch programs in 1997-1998. Groups 3, 4 and 5 are defined similarly. Group 5 districts have the highest poverty rates and were eligible for the most generous subsidies. Figure 2 presents the ratio of usage for each group relative to group 1.

As shown in figure 1, in 1996-1997 and 1997-1998 there was a strong negative correlation between district poverty rates and Internet access. In the first year of the data, the richest schools had almost 50 percent more Internet classrooms per teacher than the poorest group, for instance. Over the next year (still before the E-Rate program), this discrepancy got even larger. Once the E-Rate program began in 1998, however, and the two lowest groups began receiving a large subsidy relative to the highest group, their relative number of Internet connections accelerated until, by 2000 , some actually exceeded the connections in the richest school districts. This pattern can be seen clearly in figure 2 . For each year, the figure shows the mean number of Internet classrooms per teacher in each group relative to the wealthiest group of schools. The figure highlights the reversal in Internet access rates of rich and poor schools-a 
closing of the digital divide - that occurred in the years in which the E-Rate subsidy was offered. It is also clear that most of the catch-up occurred among the poorest sets of schools, those eligible for the largest subsidies.

\section{Identification}

In this section we expand the suggestive analysis presented above to a regression framework. Motivated by figure 1, to identify the effect of the subsidy on Internet investment we estimate the following investment equation

$$
\Delta I_{s t}=\beta s_{d t}+\alpha_{s}+\delta_{t}+\gamma_{1} m_{s t}+\gamma_{2} m_{s t}^{2}+\varepsilon_{s t}
$$

where $\Delta I_{s t}=I_{s t}-I_{s t-1}$ is the number of Internet classrooms added to school $s$ in year $t, s_{d t}$ is the subsidy rate received by district $d, \alpha_{s}$ and $\delta_{t}$ are respectively school and year effects, $m_{s t}$ is the fraction of students eligible for the federal school lunch program, and $\varepsilon_{s t}$ is an error term. The school effects $\left(\alpha_{s}\right)$ identify consistent differences in Internet investment rates over the sample period, or put differently school-specific trends in Internet access. The coefficient of interest is $\beta$, which measures the effect of the subsidy on Internet investment. Note that $s_{d t}$ is zero in all years prior to 1998 , and later is calculated as

$$
s_{d t}=f\left(m_{d t, A=1}\right)
$$

where $m_{d t, A=1}$ is the fraction of students eligible for the federal school lunch program in the schools included on district $d$ 's E-Rate application, and $f($.$) is defined as shown in table 1$. We observe $s_{d t}$ in the administrative E-Rate data. This subsidy rate depends on which schools are included on the E-Rate application. Because this decision may be correlated with $s_{d t}$, we 
compute an alternative subsidy, the subsidy the district would have received if it had been forced to include every school in the district on the application. This subsidy is computed as

$$
\tilde{s}_{d t}=f\left(m_{d t}\right)
$$

where $m_{d t}$ is the fraction of students eligible for free or reduced price lunch in all of district $d$.

We present estimates of equation (1) using both $s_{d t}$ and $\tilde{s}_{d t}$.

If the subsidy induced Internet investment, it is natural to ask whether this increase in Internet access led to changes in student achievement. To this end, we estimate the following test score equation

$$
\Delta T_{s t+1}=\beta^{\prime} s_{d t}+\alpha_{s}^{\prime}+\delta_{t}^{\prime}+\gamma_{1}^{\prime} m_{s t}+\gamma_{2}^{\prime} m_{s t}^{2}+\varepsilon_{s t}^{\prime}
$$

where $\Delta T_{s t}=T_{s t+1}-T_{s t}$ is the one-year change in the test score. The specification allows a year for Internet access to affect student achievement. Note that if $\varepsilon_{s t}$ and $\varepsilon_{s t}^{\prime}$ are uncorrelated, $\beta^{\prime} / \beta$ is the Instrumental Variables (IV) estimate the effect of Internet access on test scores.

\section{Estimates}

We now present estimates using the framework developed in the previous section. The suggestive analysis in section III highlights strong trends in Internet access and a significant relative increase in investment by high-poverty schools when the subsidy is offered. The regression framework includes year effects to control for secular trends in Internet investment rates, school effects to control for persistent differences in technology investment rates, and poverty measures to control for convergence related to income levels. The analysis asks whether schools with more generous subsidies increased Internet investment rates relative to secular trends in a way unexplained by poverty levels. 
The results in column 1 look at all schools that applied for the E-Rate program. The estimate of $\beta$ is positive and significant implying that schools facing the biggest subsidy starting in 1998, did have larger increases in the growth rate of Internet access. ${ }^{\text {日 }}$ The magnitude indicates that a ten-percentage-point increase in the E-Rate subsidy for appliers was associated with an increase in the growth rate of Internet access of 0.78 classrooms per year. This estimate corresponds to an elasticity of Internet investment with respect to the first subsidy dollar of -2.27. Of course, since this is a linear specification, the marginal elasticity declines as the subsidy increases. The marginal elasticity of Internet investment for appliers who are already at the mean subsidy rate of 50.5 percent is closer to -0.53 .

Using these results, we can estimate the total impact of the E-Rate program on Internet adoptions among the appliers. For the mean school, if the subsidy rate were zero, the predicted number of Internet connected classrooms would be 14.7 by the end of the sample period (2000-01). In fact, the true level with the subsidy was some $66 \%$ higher at 24.4 . We attribute this rather substantial difference to the E-Rate subsidy. Given the mean underlying trend growth in Internet connections estimated in the regression, however, this is the equivalent of moving up adoption by almost four years (i.e., if would have taken 3.8 extra years of trend growth if there were no subsidy to get to the level of Internet use observed in the last year of the data).

One alternative explanation of the results might be that as computer prices fall over time, poor schools increasingly find it worthwhile to get connected where in earlier periods they did not (although this does not explain why the gap between rich and poor schools expanded in the year before the E-Rate program started). Or similarly, there could be some other unobserved variable, correlated with being poor, that was increasing relative Internet investment in the time

\footnotetext{
${ }^{9}$ The standard errors are corrected to account for within-district correlation resulting from the fact that there is not school level variation in the subsidy rate every year.
} 
period. As a comparison, we look at the Internet investment of schools that did not apply for the E-Rate program. By definition, these schools do not have an observed subsidy rate so we give each school the subsidy rate they would have received if their entire district had applied together. These non-applying schools show no sensitivity to the subsidy rate. ${ }^{0}$ The coefficient is small and not significant.

A second alternative explanation is that the selective nature of the sample of appliers is biasing the results. Because subsidy rates do not reach 100 percent, districts with greater demand for Internet investment should be more likely to apply for E-Rate funds. Further, because subsidy rates are determined by the poverty rates of applicant schools, districts that apply have an incentive to include high-poverty (and exclude low-poverty) schools on their applications. This incentive is offset by efforts to ensure that E-Rate funds only go towards work done at applicant schools. This is apparent in the data. Table 4 compares three groups of schools in 1998 and 1999: schools that applied for E-Rate funds (column 1), schools that did not apply but were in districts where other schools applied (column 2), and schools that did not apply in districts where no one applied (column 3).

Districts that applied had higher school lunch eligibility rates (i.e., higher subsidy rates) than districts that did not. And within districts that applied, the schools that took part had higher school lunch eligibility rates than those that did not participate. Note that schools appear to have reacted fairly strongly to the economic incentives created by the program rules. This piece of evidence is a window into the management of public schools and may be suggestive of how they respond to outside economic forces. It also suggests there is a selection problem that we must deal with in the estimation. Note, however, that in our regression results, we control for the

\footnotetext{
${ }^{10}$ Comparing columns 1 and 2 is not a direct test of the impact of the E-Rate program, however, since it is still possible that only schools without an interest in technology choose not to apply for E-Rate funding and this unobservable difference accounts for the different price sensitivities across the specifications.
} 
school's poverty rate in a flexible way so bias can only result if selection is based on something other than just the school lunch percentage.

To deal with selection bias, we combine schools that applied for E-Rate funding with schools that did not and assign each of them the subsidy rate they would get if their entire school district applied (results are very similar using the rate that the individual school would get if they applied alone). The advantage is that this strategy avoids any problems caused by districts selectively choosing which schools to include on applications. The disadvantage is that it generates measurement error in the subsidy rate variable by assigning subsidy rates to schools that did not apply (and thus cannot be responsive in the data). Thus, this strategy will tend to produce an underestimate of the impact of the subsidy. We present this result in column 3 . The coefficient is smaller than just for the appliers but is still fairly large, positive and significant. The first dollar price elasticity is now -0.96 .

A third alternative explanation is that there are diminishing returns to expanding Internet connections so schools that already have a lot of Internet connections will eventually slow down their growth relative to schools that do not. To the extent the late-adopters are high-poverty schools, the diminishing returns story could generate a spurious correlation with the subsidy rate. In our specification, which assumes each school has a permanent trend in Internet investment, we have ruled out diminishing returns. We examine this possibility in column 4 by interacting the subsidy rate variable with the number of Internet connections the school had at the start of the sample. If the diminishing returns argument is relevant in our time period, this interaction should come in with a negative sign (greater connections to start leads to less price sensitivity). Note that we do not include the initial number of connections at the school on its own because this is absorbed in the school fixed effect. 
The results show no significant difference in price sensitivity between schools that start with a large number of Internet connections and schools that start with a small number. We also estimate the regression interacting the effect of the subsidy with the starting number of computers rather than number of Internet connections. Here, if anything, the sensitivity is actually greater among those that started with more computers rather than less. The estimates shown in column 5 indicate schools that started with more computers in 1996-97 were significantly more responsive to the subsidy. The school with the mean number of computers in 1996-97 was more than twice as sensitive to the E-Rate subsidy than a school with no computers. Perhaps this should not be surprising considering computers and Internet access are complements. However, if our results were picking up spurious correlations due to diminishing returns, or some other kind of mean reversion, we would expect to see schools with more computers appear less—not more-responsive.

\section{Who is Most Price Sensitive?}

The previous results, then, point to a significant impact of the E-Rate subsidy on public schools' Internet investment decisions. In this section we explore what types of schools are most sensitive to the subsidy.

Our first results, presented in table 5, examine differences in price-sensitivity between elementary, middle and high schools. 11 These are shown in columns 1-3. The results indicate that high schools have little sensitivity and that elementary schools are the most sensitive. These regressions include all schools (appliers and non-appliers) to fully account for the selection

\footnotetext{
${ }^{11}$ Elementary Schools are defined as schools that house at least one grade below $6^{\text {th }}$. Middle Schools are defined as schools that house at least one of the $6^{\text {th }}, 7^{\text {th }}$ or $8^{\text {th }}$ grades. And, High Schools are schools that house at least one grade above $9^{\text {th }}$. Note that these definitions are not mutually exclusive.
} 
biases. Perhaps high schools would all have increased Internet access regardless of the price, whereas elementary schools are only willing to invest in technology if it is highly subsidized.

Next, in columns 4 and 5, we present estimates for urban and rural schools. The results indicate that the rural schools are rather substantially less responsive to the subsidy program than are urban schools. In column 6 we interact the subsidy rate with the share of students in the school that are black, Hispanic, white and Asian. Interestingly, the sensitivity is significantly higher among schools that are heavily black and Hispanic. The sensitivity of schools with high white and Asian student populations is significantly smaller than the black and Hispanic coefficients. Again note that these regressions do control for poverty level through the school lunch percentage so race is not just a simple proxy for poverty level. It is possible, however, that conditional on poverty status, higher minority population schools are more budget constrained and therefore more sensitive to the subsidy rate.

\section{Outcomes}

The analysis above presents evidence that is fairly clear on the success of the E-Rate program in regards to its primary goal of getting classrooms connected to the Internet, particularly at disadvantaged schools (see the statements of Riley, Glickman and Kantor, 1996; Gore, 1997). In this section, however, we extend the evaluation to the next logical level, which is to look at whether such investment has an impact on student performance. Many of the most prominent supporters of the E-rate program, such as Clinton's Secretary of Education Richard Riley, argued that the program should aspire to more than just wiring schools, that it "must show that it really makes a difference in the classroom, and that means helping students to learn the basics and other core subjects to high standards." (Riley, 1997). 
In this section, we present some reduced-form estimates of the effect of the E-Rate subsidy on student test scores. One can interpret the ratio of these coefficients to the coefficient from the previous sections (.048) as instrumental variables estimates of the effect of Internet access on student test scores.

We measure student achievement with the Stanford Achievement Test, which has been given every year to each public school student in California beginning with the 1997-98 school year. We use three measures of school-level achievement: the mean test score in the school, the fraction of students scoring above the $75^{\text {th }}$ percentile score for the state, and the fraction of students scoring above the $25^{\text {th }}$ percentile score for the state. We allow Internet access to affect student achievement with a one-year lag, and estimate specifications analogous to those reported in table 3.

The results are presented in table 6 . The dependent variable is the increase in the school's test score and the regressor of interest is the subsidy rate. In the reported specifications, we use the subsidy rate that the district would face if each school were included on the application. We report estimates for math, reading and science test scores.

The results show no evidence that Internet investment had any measurable effect on student achievement. None of the estimates reported in the table are statistically different from zero, and in almost all cases the 95 percent confidence interval can rule out effects of any significant magnitude. To see this, notice that the coefficient estimate of 0.002 on the mean math score implies a 90 percent subsidy rate would increase math test scores by 0.18 points. The standard deviation of school-level math scores is 39.6 points. Notice also, that the point estimate implies adding one Internet classroom increases test scores by .04 points $(.002 / .048)$. Thus, it would take 1,000 extra Internet classrooms to increase a school's mean math score by 40 points, 
or one standard deviation. Point estimates are larger for elementary and middle schools, and for the fraction of students scoring above the statewide $75^{\text {th }}$ percentile, though none is statistically significant.

It is possible that it is too early to evaluate long-term investments in information technology or that the gains took place in areas other than test scores (better researched papers, for example), but thus far at least the increase of Internet investment appears to have not had a measurable impact on student achievement. The lack of impact is certainly consistent with the evidence discussed in Department of Education (2000b) that only one third of teachers reported that they were well prepared or very well prepared to use computers and the Internet or in Clarkson (2000) that most teachers surveyed are "novice or completely inexperienced" with computers.

VIII. Conclusion

The rise of the Internet and the spread of a digital divide led to concern among policymakers about the implication for long-term economic inequality. This concern inspired the expansion of the Universal Service Fund to subsidize Internet and communication technology investment by more than $\$ 2$ billion per year (itself more than half of all public school computer spending in the year). The subsidy, called the E-Rate, was implemented in 1998 and provided a sliding scale subsidy between 20 and 90 percent.

In this paper, we have taken a first step towards evaluating the effect the E-Rate subsidy had on Internet investment in California's public schools. We find that despite the strong pre1998 income gradient of Internet access, E-Rate funding went disproportionately to low-Internet schools. We also show evidence that the E-Rate subsidy led to significant increases in Internet 
investment by California schools. Overall by 2000, there were some 66 percent more classrooms with Internet connections than there would have been without the subsidy. This is the equivalent of accelerating Internet investment by about 4 years.

Urban schools, predominantly black and Hispanic schools and lower and middle schools are disproportionately responsive to the subsidy. Predominantly white and Asian schools, rural schools and high schools show less sensitivity to the subsidy rates.

Despite the noticeable impact on the expansion of the Internet, however, there is very little evidence that the program has had any measurable outcome on student achievement, thus far, as measured by test scores in a variety of subjects. 
FIGURE 1: TREND IN CLASSROOMS WITH INTERNET ACCESS PER TEACHER BY 1997-1998 POVERTY STATUS

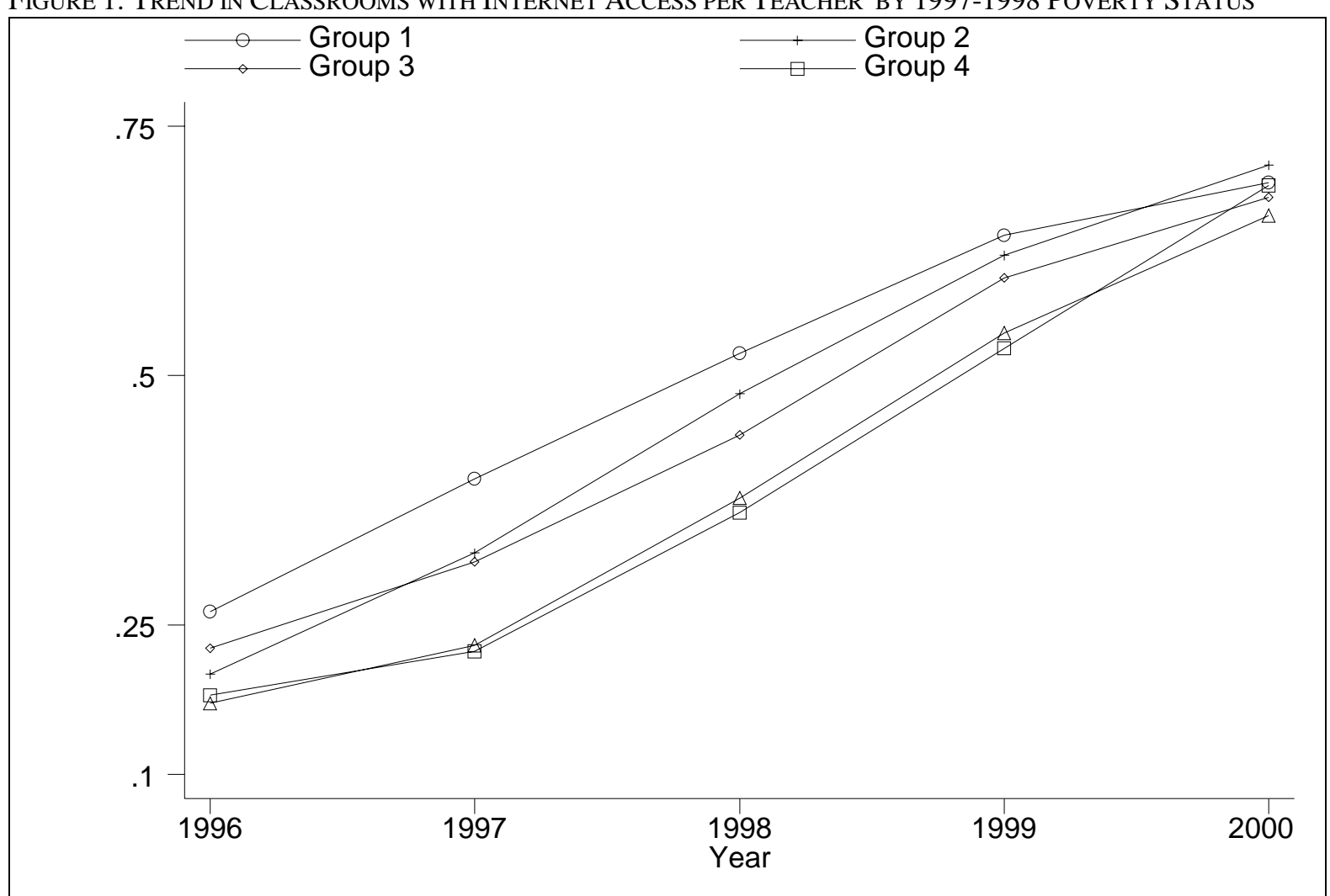

Note: The figure shows yearly averages of the number of classrooms with Internet access per teacher for five groups of districts. The 1996-1997 school year is labeled 1996, etc. Group 1 is districts with 0 to 20 percent of their students eligible for the federal free or reduced lunch programs in 1997-1998, the year before the availability of the E-Rate subsidy. Similarly, Group 2: 20 to 40 percent eligible; Group 3: 40 to 60 percent eligible; Group 4: 60 to 80 percent eligible; Group 3: 80 to 100 percent eligible. 
FIGURE 2: RELATIVE TREND IN CLASSROOMS WITH INTERNET ACCESS PER TEACHER

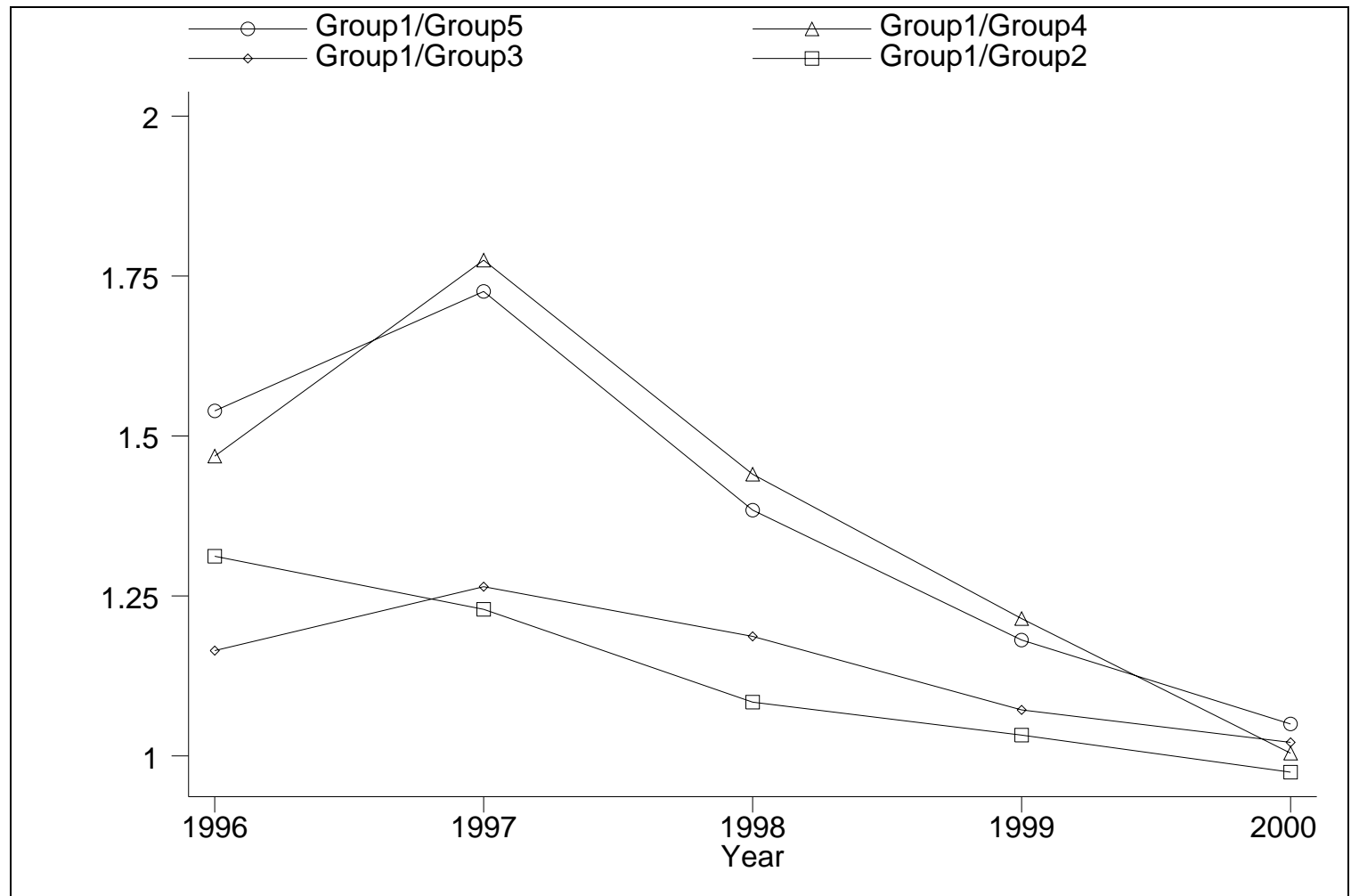

Note: The figure shows yearly ratios of the number of classrooms with Internet access per teacher for four groups of districts, relative to a fifth group. The 1996-1997 school year is labeled 1996, etc. Group 1 (the reference group) is districts with 0 to 20 percent of their students eligible for the federal free or reduced lunch programs in 1997-1998, the year before the availability of the E-Rate subsidy. Similarly, Group 2: 20 to 40 percent eligible; Group 3: 40 to 60 percent eligible; Group 4: 60 to 80 percent eligible; Group 3: 80 to 100 percent eligible. 


\begin{tabular}{|c|c|c|c|c|c|c|}
\hline $\begin{array}{c}\% \text { of Students Eligible for } \\
\text { National School Lunch } \\
\text { Program }\end{array}$ & $\begin{array}{l}\text { Urban Discount } \\
\text { Percentage }\end{array}$ & $\begin{array}{l}\text { Rural Discount } \\
\text { Percentage }\end{array}$ & $\begin{array}{c}\% \text { of } \\
\text { California Districts } \\
\text { in Category }\end{array}$ & $\begin{array}{l}\text { Total E-Rate Funds } \\
\quad \text { (in } \$ \text { millions) }\end{array}$ & $\begin{array}{l}\text { Total } \\
\text { E-Rate Funds per } \\
\text { Pupil } \\
\text { (in \$) }\end{array}$ & $\begin{array}{c}\text { Internet } \\
\text { Classrooms per } \\
\text { Teacher in } \\
\text { 1996-97 }\end{array}$ \\
\hline$<1$ & 20 & 25 & 10.1 & 16 & 127 & .45 \\
\hline $1-19$ & 40 & 50 & 16.1 & 14 & 17 & .21 \\
\hline $20-34$ & 50 & 60 & 19.7 & 38 & 35 & .14 \\
\hline $35-49$ & 60 & 70 & 15.5 & 36 & 40 & .15 \\
\hline $50-74$ & 80 & 80 & 24.8 & 597 & 248 & .12 \\
\hline $75-100$ & 90 & 90 & 13.8 & 178 & 341 & .08 \\
\hline
\end{tabular}

Note: The table lists the subsidy rate awarded to schools in each of six categories based on the fraction of students eligible for the federal free and reduced price school lunch programs. Columns 5 and 6 of the table also lists the totals of E-Rate funds awarded to California public schools in each category in the first three years of the program. Column 7 of the table lists the ratio of Internet classrooms in 1996-97 to full-time equivalent teachers in California public schools in each category. 


\begin{tabular}{|c|c|c|c|c|c|}
\hline & 1996-1997 & $1997-1998$ & 1998-1999 & $1999-2000$ & $2000-2001$ \\
\hline $\begin{array}{l}\text { Technology } \\
\text { Fraction of Schools with Any } \\
\text { Internet Connections in } \\
\text { Classrooms }\end{array}$ & $\begin{array}{l}.46 \\
(.50)\end{array}$ & $\begin{array}{l}.55 \\
(.50)\end{array}$ & $\begin{array}{l}.70 \\
(.46)\end{array}$ & $\begin{array}{l}.77 \\
(.42)\end{array}$ & $\begin{array}{l}.84 \\
(.36)\end{array}$ \\
\hline $\begin{array}{l}\text { Classrooms with Internet } \\
\text { Connections }\end{array}$ & $\begin{array}{c}4.5 \\
(12.4)\end{array}$ & $\begin{array}{c}7.7 \\
(16.8)\end{array}$ & $\begin{array}{l}11.8 \\
(12.9)\end{array}$ & $\begin{array}{l}17.7 \\
(33.4)\end{array}$ & $\begin{array}{l}21.7 \\
(29.3)\end{array}$ \\
\hline $\begin{array}{l}\text { Classrooms with Internet } \\
\text { Connections per Teacher }\end{array}$ & $\begin{array}{l}.17 \\
(.42)\end{array}$ & $\begin{array}{l}.26 \\
(.90)\end{array}$ & $\begin{array}{l}.38 \\
(.54)\end{array}$ & $\begin{array}{l}.54 \\
(.74)\end{array}$ & $\begin{array}{l}.66 \\
(.81)\end{array}$ \\
\hline $\begin{array}{l}\text { Fraction of Schools with Any } \\
\text { Computers for Instructional } \\
\text { Purposes }\end{array}$ & $\begin{array}{l}.94 \\
(.23)\end{array}$ & $\begin{array}{l}.93 \\
(.26)\end{array}$ & $\begin{array}{l}.96 \\
(.18)\end{array}$ & $\begin{array}{l}.97 \\
(.17)\end{array}$ & $\begin{array}{l}.98 \\
(.14)\end{array}$ \\
\hline $\begin{array}{l}\text { Computers for Instructional } \\
\text { Purposes }\end{array}$ & $\begin{array}{c}62.2 \\
(63.4)\end{array}$ & $\begin{array}{c}70.1 \\
(73.0)\end{array}$ & $\begin{array}{l}80.6 \\
(83.7)\end{array}$ & $\begin{array}{c}92.0 \\
(97.0)\end{array}$ & $\begin{array}{l}102.6 \\
(107.7)\end{array}$ \\
\hline $\begin{array}{l}\text { Computers for Instructional } \\
\text { Purposes per Teacher }\end{array}$ & $\begin{array}{c}2.1 \\
(1.8)\end{array}$ & $\begin{array}{c}2.2 \\
(2.4)\end{array}$ & $\begin{array}{c}2.5 \\
(3.4)\end{array}$ & $\begin{array}{l}2.8 \\
(2.2)\end{array}$ & $\begin{array}{l}3.1 \\
(2.2)\end{array}$ \\
\hline Number of Districts & 1,056 & 1,053 & 1,057 & 1,055 & 1,055 \\
\hline Number of Schools & 7,991 & 8,186 & 8,340 & 8,641 & 8,812 \\
\hline \multicolumn{6}{|l|}{$\begin{array}{l}\text { E-Rate Funds: } \\
\text { (in \$000) }\end{array}$} \\
\hline Total Funds Committed: CA & & & 208,000 & 254,000 & 475,000 \\
\hline $\begin{array}{l}\text { Total Funds Committed: CA } \\
\text { in Data Used in the Analysis }\end{array}$ & & & 181,000 & 222,000 & 446,000 \\
\hline Internet Access & & & 3,723 & 7,370 & 5,119 \\
\hline Telecommunications & & & 46,300 & 47,300 & 54,700 \\
\hline Internal Connections & & & 126,000 & 166,000 & 386,000 \\
\hline
\end{tabular}




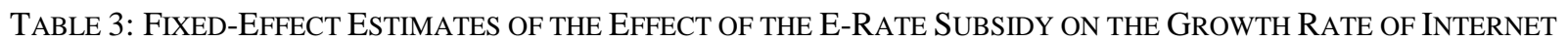
ACCESS

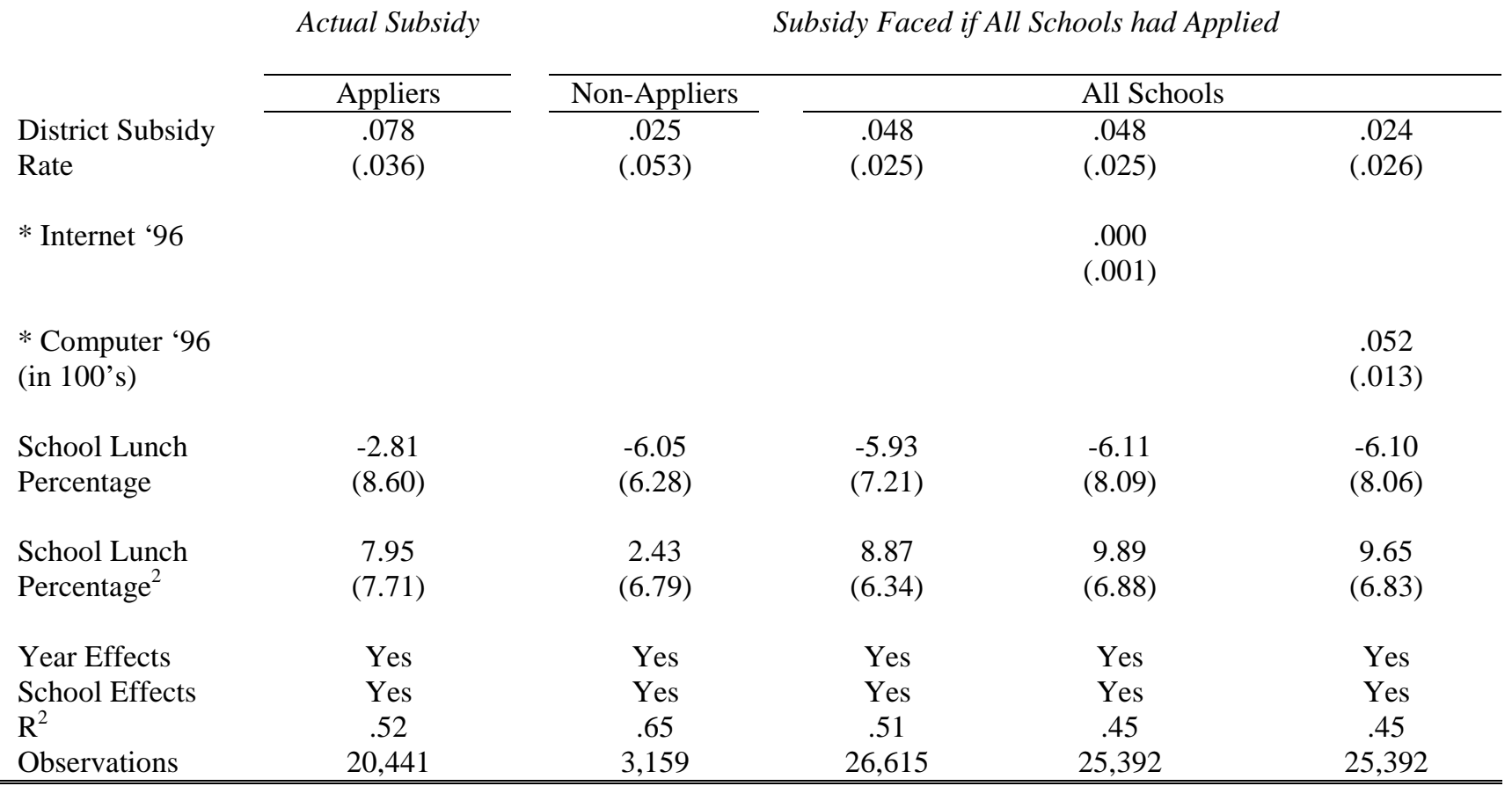

Note: The dependent variable is the increase in the number of classrooms with Internet access since last year. All standard errors account for district-level correlation in the error term. Observations are at the school-level. There is a separate observation for each year of the sample, from 1997-1998 to 2000-2001. Elementary Schools are defined as schools that house at least one grade below $6^{\text {th }}$. Middle Schools are defined as schools that house at least one of $6^{\text {th }}, 7^{\text {th }}$, or $8^{\text {th }}$ grades. High Schools are defined as schools that house at least one grade above $9^{\text {th }}$. 
Applied:

\begin{tabular}{|c|c|c|c|}
\hline & $\begin{array}{l}\text { School: Yes } \\
\text { District: Yes }\end{array}$ & $\begin{array}{l}\text { School: No } \\
\text { District: Yes }\end{array}$ & $\begin{array}{l}\text { School: No } \\
\text { District: No }\end{array}$ \\
\hline $\begin{array}{l}\text { School Lunch } \\
\text { Percentage }\end{array}$ & $\begin{array}{l}.51 \\
(.30)\end{array}$ & $\begin{array}{l}.40 \\
(.34)\end{array}$ & $\begin{array}{l}.33 \\
(.30)\end{array}$ \\
\hline Enrollment & $\begin{array}{c}773 \\
(599)\end{array}$ & $\begin{array}{c}502 \\
(599)\end{array}$ & $\begin{array}{c}574 \\
(544)\end{array}$ \\
\hline $\begin{array}{l}\text { Pupil-Teacher } \\
\text { Ratio }\end{array}$ & $\begin{array}{l}20.7 \\
(4.0)\end{array}$ & $\begin{array}{l}21.2 \\
(25.1)\end{array}$ & $\begin{array}{l}19.6 \\
(9.7)\end{array}$ \\
\hline Percent White & $\begin{array}{l}.38 \\
(.29)\end{array}$ & $\begin{array}{l}.43 \\
(.30)\end{array}$ & $\begin{array}{l}.56 \\
(.27)\end{array}$ \\
\hline Percent Black & $\begin{array}{l}.09 \\
(.13)\end{array}$ & $\begin{array}{l}.11 \\
(.15)\end{array}$ & $\begin{array}{l}.04 \\
(.07)\end{array}$ \\
\hline Percent Hispanic & $\begin{array}{l}.41 \\
(.29)\end{array}$ & $\begin{array}{l}.35 \\
(.27)\end{array}$ & $\begin{array}{l}.30 \\
(.26)\end{array}$ \\
\hline Percent Asian & $\begin{array}{l}.11 \\
(.14)\end{array}$ & $\begin{array}{l}.08 \\
(.10)\end{array}$ & $\begin{array}{l}.07 \\
(.10)\end{array}$ \\
\hline Elementary School & $\begin{array}{l}.70 \\
(.46)\end{array}$ & $\begin{array}{l}.55 \\
(.50)\end{array}$ & $\begin{array}{l}.63 \\
(.48)\end{array}$ \\
\hline Middle School & $\begin{array}{l}.57 \\
(.49)\end{array}$ & $\begin{array}{l}.55 \\
(.50)\end{array}$ & $\begin{array}{l}.53 \\
(.50)\end{array}$ \\
\hline High School & $\begin{array}{l}.17 \\
(.38)\end{array}$ & $\begin{array}{l}.39 \\
(.49)\end{array}$ & $\begin{array}{l}.26 \\
(.44)\end{array}$ \\
\hline $\begin{array}{l}\text { Computers per } \\
\text { Student }\end{array}$ & $\begin{array}{l}.14 \\
(.12)\end{array}$ & $\begin{array}{l}.21 \\
(.48)\end{array}$ & $\begin{array}{l}.19 \\
(.34)\end{array}$ \\
\hline $\begin{array}{l}\text { Internet } \\
\text { Classrooms per } \\
\text { Student }\end{array}$ & $\begin{array}{l}.02 \\
(.03)\end{array}$ & $\begin{array}{l}.04 \\
(.12)\end{array}$ & $\begin{array}{l}.04 \\
(.09)\end{array}$ \\
\hline \multicolumn{4}{|c|}{$\begin{array}{l}\text { Note: The table reports means of selected characteristics for three groups of California } \\
\text { schools in 1998-99 and 1999-2000. The first column included schools listed on } \\
\text { applications for E-Rate funds. The second column includes schools in districts that } \\
\text { applied for E-Rate funds, but not listed on applications. The third column includes } \\
\text { schools in districts that did not apply for E-Rate funds. All category definitions are } \\
\text { year-specific. }\end{array}$} \\
\hline
\end{tabular}


Table 5: Who Is Most Price Sensitive?

\begin{tabular}{|c|c|c|c|c|c|c|c|}
\hline \multirow[b]{2}{*}{$\begin{array}{l}\text { District } \\
\text { Subsidy Rate }\end{array}$} & \multirow{2}{*}{$\begin{array}{c}\begin{array}{c}\text { Elementary } \\
\text { Schools }\end{array} \\
.075 \\
(.023)\end{array}$} & \multirow{2}{*}{$\begin{array}{c}\text { Middle } \\
\text { Schools } \\
\\
.050 \\
(.029)\end{array}$} & \multirow{2}{*}{$\begin{array}{c}\text { High Schools } \\
\begin{array}{c}-.002 \\
(.052)\end{array}\end{array}$} & \multirow{2}{*}{$\begin{array}{c}\text { Urban } \\
\text {.054 } \\
(.028)\end{array}$} & \multirow{2}{*}{$\begin{array}{c}\text { Rural } \\
.017 \\
(.031)\end{array}$} & \multicolumn{2}{|c|}{ All } \\
\hline & & & & & & $\begin{array}{l}\text { Subsidy Rate } \\
* \% \text { White }\end{array}$ & $\begin{array}{l}.039 \\
(.027)\end{array}$ \\
\hline & & & & & & * \% Hispanic & $\begin{array}{l}.076 \\
(.024)\end{array}$ \\
\hline & & & & & & $* \%$ Black & $\begin{array}{c}.059 \\
(.034)\end{array}$ \\
\hline & & & & & & $* \%$ Asian & $\begin{array}{l}.020 \\
(.040)\end{array}$ \\
\hline & & & & & & $* \%$ Other & $\begin{array}{l}.001 \\
(.036)\end{array}$ \\
\hline $\begin{array}{l}\text { School Lunch } \\
\text { Percentage }\end{array}$ & $\begin{array}{l}-3.91 \\
(5.81)\end{array}$ & $\begin{array}{l}-9.47 \\
(7.00)\end{array}$ & $\begin{array}{c}-5.56 \\
(11.14)\end{array}$ & $\begin{array}{l}-4.58 \\
(9.06)\end{array}$ & $\begin{array}{l}-6.56 \\
(5.00)\end{array}$ & & $\begin{array}{l}-3.45 \\
(5.79)\end{array}$ \\
\hline $\begin{array}{l}\text { School Lunch } \\
\text { Percentage }^{2}\end{array}$ & $\begin{array}{c}7.66 \\
(6.12)\end{array}$ & $\begin{array}{l}12.96 \\
(7.34)\end{array}$ & $\begin{array}{l}5.25 \\
(9.13)\end{array}$ & $\begin{array}{l}8.98 \\
(7.70)\end{array}$ & $\begin{array}{c}4.87 \\
(4.82)\end{array}$ & & $\begin{array}{c}7.44 \\
(6.06)\end{array}$ \\
\hline Year Effects & Yes & Yes & Yes & Yes & Yes & & Yes \\
\hline School Effects & Yes & Yes & Yes & Yes & Yes & & Yes \\
\hline $\mathrm{R}^{2}$ & .64 & .61 & .59 & .51 & .47 & & .64 \\
\hline No. Obs. & 18,182 & 14,938 & 5,565 & 23,206 & 3,409 & & 18,176 \\
\hline
\end{tabular}




\begin{tabular}{ccc}
$\begin{array}{c}\text { Test Score } \\
\text { Mean }\end{array}$ & All Schools & Elementary \\
(Std. Dev.) & & \\
\hline
\end{tabular}

Middle

High School

(Std. Dev.)

Mean:

Math

638.2

(39.6)

.002

(.018)

.028

(.032)

.024

$-.041$

(.034)

$(.081)$

Reading

640.7

(38.4)

.001

$(.022)$

.033

.021

$-.067$

$(.045)$

(.039)

$(.076)$

Science

662.7

.006

(.104)

.000

(.110)

$75^{\text {th }}$ Percentile:

Math

25.2

(18.3)

.005

(.008)

.009

.009

.002

(.010)

(.011)

(.011)

Reading

20.4

$-.002$

.005

$-.003$

$-.007$

(.007)

(.010)

(.008)

(.007)

Science

14.0

.003

.003

(12.3)

(.011)

(.011)

$25^{\text {th }}$ Percentile:

Math

69.7

(18.8)

$-.023$

(.010)

$-.019$

$-.024$

(.012)

$-.023$

(.011)

(.028)

Reading

65.7

(21.1)

$-.018$

$-.007$

$-.018$

$-.054$

(.015)

(.024)

(.014)

(.025)

Science

63.7

$-.019$

(.024)

-.019

(18.8)

(.024) 


\section{Bibliography}

Angrist, Joshua and Victor Lavy (1999), "New Evidence on Classroom Computers and Pupil Learning," NBER Working Paper \#7424.

Clarkson, Blair (2000), "Ready or Not? Not" Industry Standard, September 12, 2000

Crandall, Robert and Leonard Waverman (2000), Who Pays for Universal Service?, Brookings Institution Press (Washington, D.C.).

Eriksson, Ross, David Kaserman, and John Mayo (1998), Targeted and Untargeted Subsidy Schemes: Evidence from Post-Divestiture Efforts to Promote Universal Telephone Service," Journal of Law and Economics, vol. 41 part 1, October, pp. 477502.

Federal Communications Commission (2001), "Eligible Services List," CC Docket 9645, October 17, $2001<\mathrm{http}: / / w w w . s l . u n i v e r s a l s e r v i c e . o r g / d a t a / p d f /$

EligibleServicesList_101701.pdf, accessed December 11, 2001.

Gore, Albert (1997), Statement of the Vice-President on the FCC E-Rate Decision, issued May 7, <http://www.ed.gov/PressReleases/05-1997/97-05-07.html>, accessed 6/30/2002.

Riley, Richard (1997), Statement of U.S. Secretary of Education Richard W. Riley Re: FCC Approval of the E-Rate, issued May 7, <http://www.ed.gov/PressReleases/051997/erate.html>, accessed 6/30/2002.

Riley, Richard, Daniel Glickman, Mickey Kantor (1996), "A Plan to Implement the ERate," letter to FCC Chairman Reid Hundt, October 10, 1996, <http://www.ed.gov/ Technology/NTIA/letter.html>, accessed 6/30/2002.

Hausman, Jerry (1998), "Taxation by Telecommunications Regulation," in Tax Policy and the Economy, vol 12, James Poterba, Ed. MIT Press (Cambridge, Mass.).

Heckman, James J. (1978), "Dummy Endogenous Variables in a Simultaneous Equation System,” Econometrica, Vol. 46, No. 6, pp. 931-959.

Heckman, James J. (1979), "Sample Selection Bias as a Specification Error," Econometrica, Vol. 47, No. 1, pp. 153-161.

Lake, David (2000), “Surfing at School," The Industry Standard, October 2000, p. 117.

Puma, Michael, Duncan D. Chaplin, and Andreas D. Pape (2000), "E-Rate and the Digital Divide: A Preliminary Analysis From the Integrated Studies of Educational Technology," Mimeo, Urban Institute, September. 
Sonstelie, Jon, Eric Brunner, and Kenneth Ardon (2000), "For Better or For Worse? School Finance Reform in California," Public Policy Institute of California (San Francisco, CA).

U.S. Department of Education (1997b), "Implementing the E-Rate," August 5, <http:// www.ed.gov/Technology/implem 1.html>, accessed December 11, 2001.

U.S. Department of Education, National Center for Education Statistics (2000a), "Internet Access in U.S. Public Schools and Classrooms: 1994-1999," U.S. Department of Education Office of Research and Improvement, NCES \# 2000-086, February.

U.S. Department of Education, National Center for Education Statistics (2000b), "Teacher Use of Computers and the Internet in Public Schools," U.S. Department of Education Office of Research and Improvement, NCES \# 2000-090, April.

Walsh, Ekaterina, with Michael Gazala and Christine Ham (2000), "The Truth About the Digital Divide," Forrester Research Brief, April 11, 2000.

Wolak, Frank (1996), "Can Universal Service Survive in a Competitive Telecommunications Environment? Evidence from the United States Consumer Expenditure Survey," Information Economics and Policy, vol 8, September, 163-203. 